\title{
The Lower Palaeozoic now fully cored and logged on Bornholm, Denmark
}

\author{
Niels H. Schovsbo, Arne T. Nielsen and Kurt Klitten
}

A $558 \mathrm{~m}$ long, complete section of the Lower Palaeozoic succession preserved onshore southern Bornholm has been compiled from five fully cored scientific wells, carried out between 2005 and 2012. The scientific programme included coring and geophysical logging of the five scientific wells that yielded a total of $c .750 \mathrm{~m}$ of partially overlapping cores as well as re-logging of water wells and acquisition of shallow seismic data. The last well drilled, the Sommerodde-1, cored the youngest preserved Silurian strata on Bornholm including strata not exposed in outcrops. The well penetrated $168.1 \mathrm{~m}$ of Silurian shales, $42.7 \mathrm{~m}$ of Upper Ordovician shales and $27.9 \mathrm{~m}$ of Alum Shale before it terminated at a depth of $250.3 \mathrm{~m}$ in the Lower Cambrian Norretorp Member of the Læså Formation. The Sommerodde-1 well documents that the Lower Silurian Cyrtograptus shale is at least $91.7 \mathrm{~m}$ thick and that the Rastrites shale is $76.4 \mathrm{~m}$ thick. The complete Lower Cambrian succession has previously been covered by the $316.0 \mathrm{~m}$ deep Borggård-1 well that terminated in basement rocks (Nielsen et al. 2006).

\section{The Lower Palaeozoic in Denmark}

The Lower Palaeozoic is very thick in Denmark, locally more than $4 \mathrm{~km}$ thick, and the deposition marks the transition from passive margin to a rapidly subsiding foreland basin de-

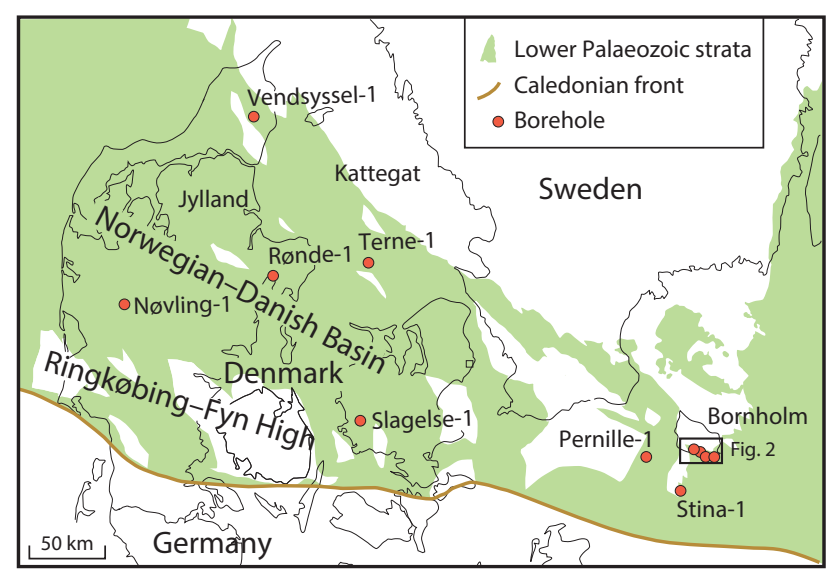

Fig. 1. Distribution of Lower Palaeozoic strata and deep wells reaching at least top Silurian in Denmark north of the Caledonian Front. The Vendsyssel-1 well is planned to be drilled in 2015. veloped in front of the Caledonian orogen towards the south and west (Lassen \& Thybo 2012). The Palaeozoic strata onshore Bornholm have been described in papers published over the last 150 years and constitute a classical topic in Danish geology. However, previous studies have primarily focused on biostratigraphical aspects. Contemporaneous strata throughout most of central and western Denmark are deeply buried and hence, have only been reached by a few deep exploration wells (Fig. 1), and thus the succession is rather poorly known. Only in Slagelse-1 and Terne-1 in Kattegat have the Palaeozoic shales been fully penetrated whereas only the topmost parts of the Silurian shales were reached by the Rønde-1, Nøvling-1, Pernille-1 and Stina-1 wells (Fig. 1). A new shale gas exploration well, Vendsyssel-1, is planned to be drilled in 2015 and is expected to penetrate the entire Lower Palaeozoic shale sequence in northern Jylland (Fig. 1).

\section{The Sommerodde-1 well}

The well was drilled as close as technically possible to the Sommerodde beach locality described by Bjerreskov \& Jørgensen (1983) where the youngest Silurian strata onshore Bornholm are exposed at low tide. Prior to drilling, a seismic section was recorded in April 2012 and relevant water well

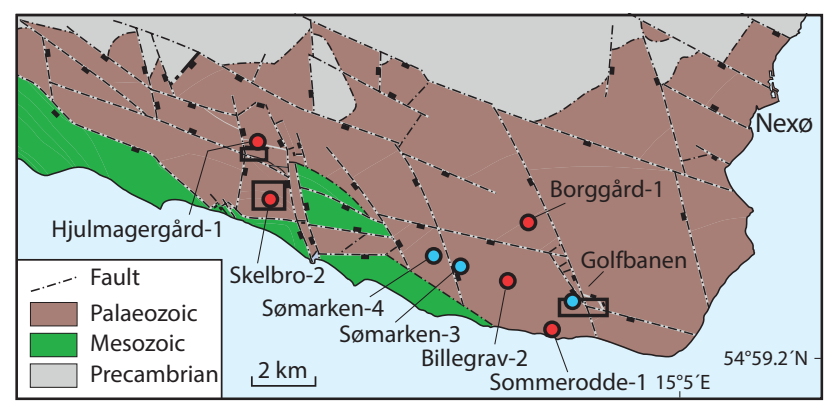

Fig. 2. Geological map of southern Bornholm showing the positions of scientific wells drilled 2005-2012. Borggård-1 (DGU 247.627), Skelbro-2 (DGU 246.817), Billegrav-2 (DGU 248.61), Hjulmagergård-1 (DGU 246.838) and Sommerodde-1 (DGU 248.62) are shown as red dots, and the re-logged water wells Sømarken-3 (DGU 248.39), Sømarken-4 (DGU 247.312) and Golfbanen-1 (DGU 248.54) are shown as blue dots. Areas where $2 \mathrm{D}$ seismic data were acquired are shown as black rectangles. The geological map is from a compilation by Graversen (2009). 


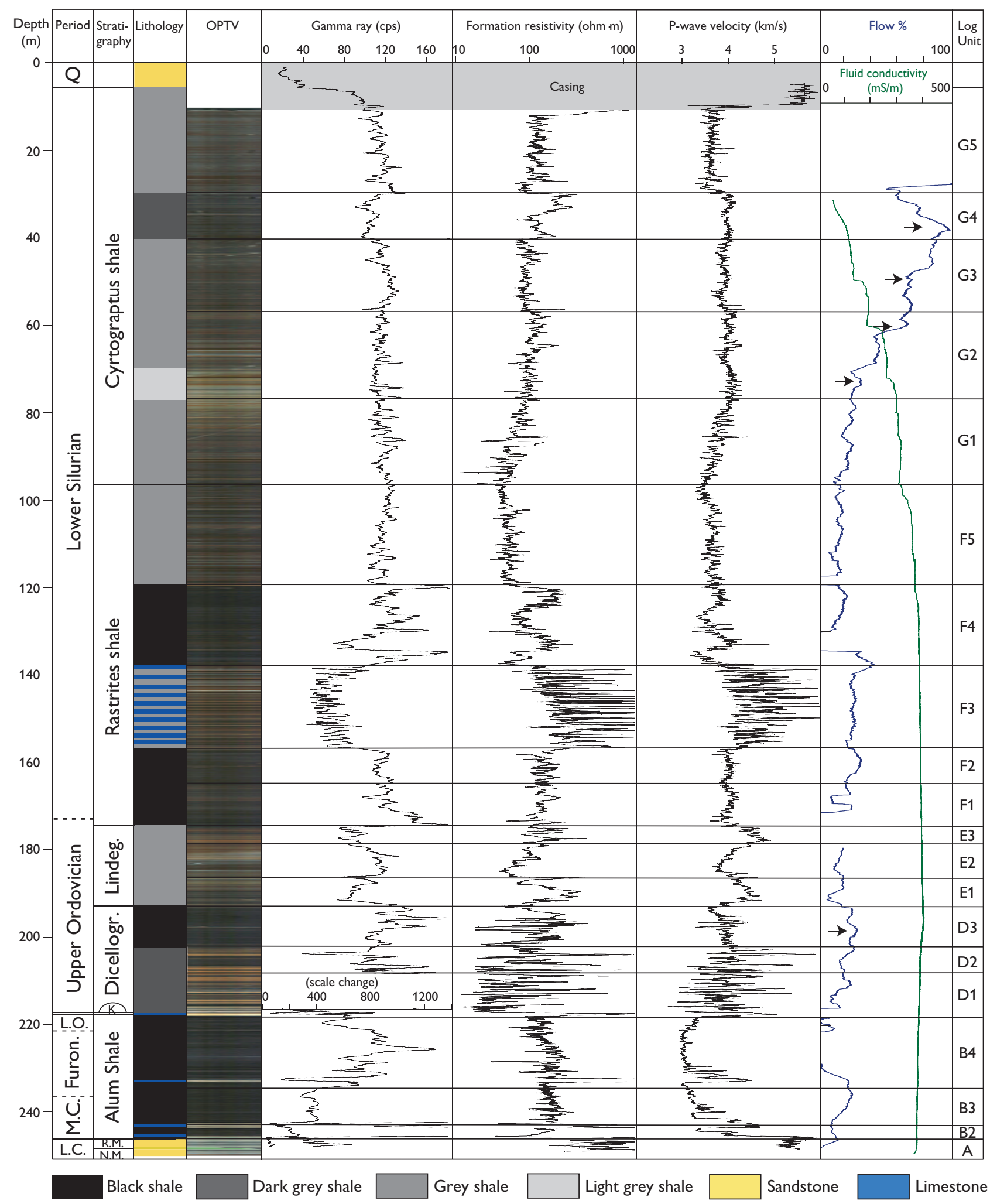

Fig. 3. Selected logs measured in the Sommerodde-1 well. The arrows indicate significant water inflow zones. The optic televiewer (OPTV) picture of the well is a $360^{\circ}$ view of the borehole wall. Flow \%: water flow scaled to the total flow of $1.4 \mathrm{~m}^{3} / \mathrm{h}$. Q: Quaternary. LO: Lower Ordovician. Furon.: Furongian. MC: Middle Cambrian. LC: Lower Cambrian. Lindeg.: Lindegård Formation. Dicellogr.: Dicellograptus shales. K: Komstad Limestone. RM: Rispebjerg Member. NM: Norretorp Member of the Læså Formation. cps: counts per second. 
reports were examined to locate potential faults in the area (Fig. 2). The well was drilled in November 2012, well logging was done by both the Geological Survey of Denmark and Greenland and Rambøll and the hole was plugged and permanently abandoned in November 2013. A total of ten log runs were made including a full wave sonic $\log$ and an optic televiewer recording that provided a high resolution image of the borehole wall (Fig. 3).

The Sommerodde- 1 well cored Silurian shales between 6.5 and $174.6 \mathrm{~m}$, Ordovician shale above the Alum Shale Formation between 174.6 and 217.3 m, a thin Komstad Limestone (Middle Ordovician) between 217.3 and $217.9 \mathrm{~m}$, the Cambro-Ordovician Alum Shale Formation between 217.9 and $245.8 \mathrm{~m}$ and Lower Cambrian sand- and siltstone between 245.8 and $250.3 \mathrm{~m}$ (Fig. 3). A total of $168.1 \mathrm{~m}$ Silurian shales were thus cored. The lower Silurian Rastrites shale was completely cored and is $76.4 \mathrm{~m}$ thick in the well. The Alum Shale Formation is $27.9 \mathrm{~m}$ thick and includes the Middle Cambrian Andrarum and Exsulans Limestone beds. The well was terminated at $250.3 \mathrm{~m}$ in the Norretorp Member of the Læså Formation after having penetrated the Rispebjerg Member (4.5 m thick).

\section{Log stratigraphy in the Sommerodde-1 well}

Pedersen \& Klitten (1990) established a detailed log stratigraphical scheme (labelled units A-G on Figs 3, 4) based on the gamma-ray variation in the Lower Palaeozoic shales on Bornholm. The log stratigraphy permitted correlation of un-cored water wells with fully cored scientific wells. The log stratigraphy was later emended to also include the resistivity log, from which more detailed lithological information can be gained (Schovsbo et al. 2011). In the Sommerodde-1 all log-based units defined by Pedersen \& Klitten (1990) were identified and the previously un-divided $G$ unit was divided into four new log units, labelled G1-G4 (Fig. 3). The units A-F were described by Schovsbo et al. (2011) and, hence, only the new log units are briefly described here.

The $\mathrm{G}$ unit is correlated here with the Cyrtograptus shale as was originally done by Pedersen \& Klitten (1990). The base of the $\mathrm{G}$ unit has not previously been cored nor recognised in logs from water wells on Bornholm. It is here placed at 98.2 $\mathrm{m}$; above this level the resistivity and sonic velocity log readings increase (Figs 3, 4). The G1 subunit is $24 \mathrm{~m}$ thick and consists of light green to dark grey shales. The unit is characterised by a steady increase in resistivity readings. Subunit G2 is $18.5 \mathrm{~m}$ thick and consists of light grey to dark green shale. Subunit G3 is $16 \mathrm{~m}$ thick and consists of light grey to dark green shale. The top of the G3 subunit is defined where an increase occurs in the resistivity log, reflecting a change

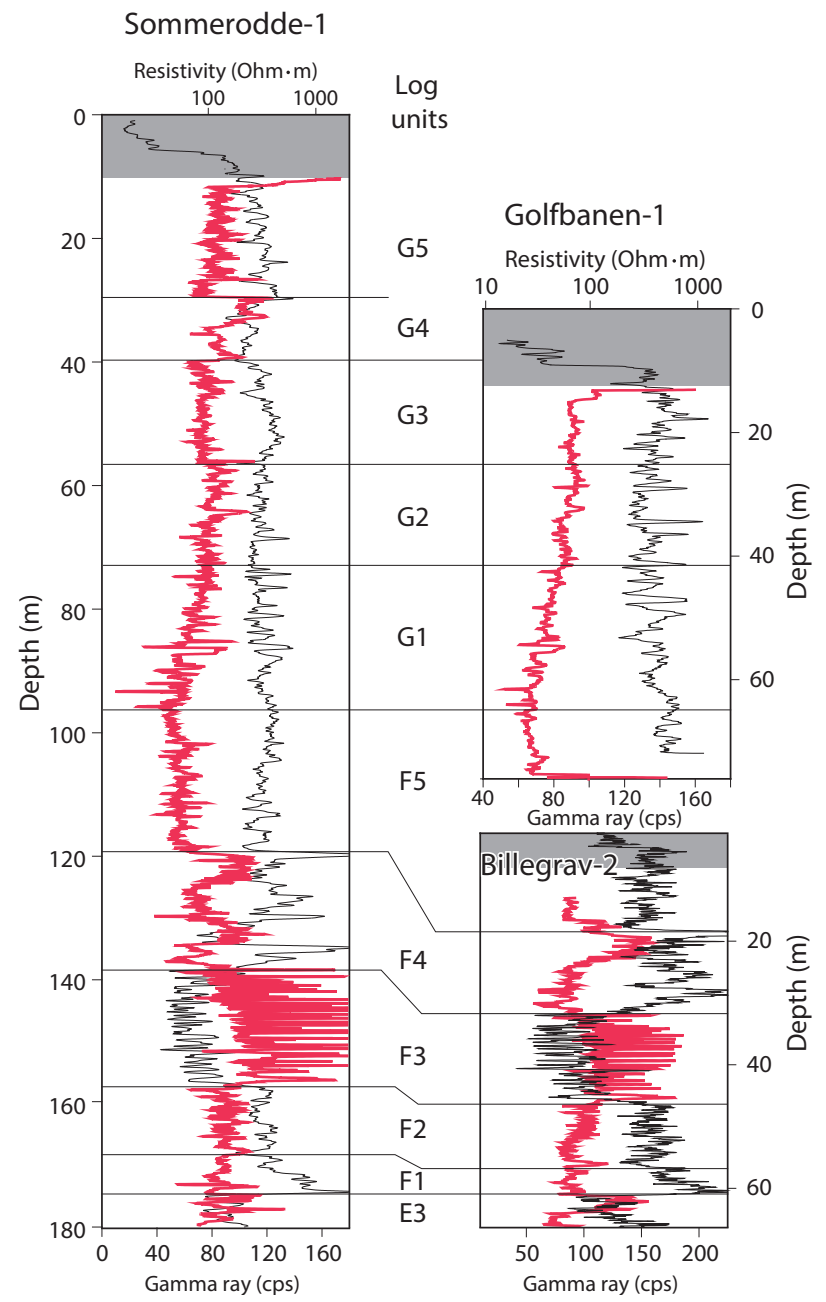

Fig. 4. Correlation of the Silurian sections in the Sommerodde-1, Billegrav-2 and Golfbanen-1 wells based on the gamma-ray (black line) and resistivity log (red line) responses. Grey intervals show intervals where the log response was measured through the steel casing.

to darker lithologies. Numerous bentonite beds characterised by low resistivity and high gamma ray readings occur in G2 and G3. Subunit G4 is a $10 \mathrm{~m}$ thick, dark-coloured interval. The subunit is readily identified in the core and on the optic televiewer log and by a slightly lower gamma-ray log response and distinctly higher resistivity readings compared to the subunits above and below. The top of the G4 subunit is defined at a point of decrease in the resistivity log. Subunit G5 is $23.5 \mathrm{~m}$ thick and comprises light grey to green shale characterised by low and stable gamma-ray values. The subunit includes numerous silty to sandy beds similar to those exposed on the beach just south of the well location (Bjerreskov \& Jørgensen 1983). 


\section{Correlation of Silurian shales on southern Bornholm}

The $G$ unit was originally defined based on the gammaray signature in the un-cored water well Golfbanen-1 that penetrated a section of the Cyrtograptus shale (Pedersen \& Klitten 1990). As part of the present study the Golfbanen-1 well was re-logged in order to expand the log signature and to enable correlation with the Sommerodde-1 well (Fig. 4). Based on comparison with the Sommerodde-1 well, the gamma ray and resistivity logs show that the Golfbanen-1 well penetrated a sequence from the G3 to the uppermost F5 unit. The Sommerodde-1 well is also correlated with the fully cored Billegrav-2 well that penetrated the succession from the lower part of the F5 unit and downwards, thereby closing the correlation gap between the Billegrav-1 well and the exposures in the Øle $\AA$ water course as presented by Pedersen \& Klitten (1990). Several of the Rastrites shale log units are slightly thicker in the Sommerodde-1 well than in the Billegrav-2 well (Fig. 4). In the latter several fault zones occur in this interval and it appears that parts of the section are missing due to faulting. In the Sommerodde- 1 well no fault zones are identified and it is believed that the recorded thicknesses reflect the true stratigraphical thicknesses.

\section{Water-flow properties}

The water inflow in Sommerodde-1 was evaluated from an impeller flow log during discharge of $1.4 \mathrm{~m}^{3} / \mathrm{h}$ supplemented by the fluid conductivity log measured during the same discharge from the well. Together the two logs show that most of the inflow took place within the uppermost $75 \mathrm{~m}$ of the well (Fig. 3). The inflow rates decrease rapidly with depth and the section below $80 \mathrm{~m}$ contributes with less than $20 \%$ of the total inflow into the well. The water conductivity is highest in the Alum Shale Formation and in the lower part of the Rastrites shale, $350-400 \mathrm{mS} / \mathrm{m}$, but from a depth of $125 \mathrm{~m}$ and upwards several small inflow sources with lower conductivity stepwise reduce the conductivity of the upwards flowing water until it has a conductivity of $50 \mathrm{mS} / \mathrm{m}$ (Fig. 3). In spite of the many inflow points the specific yield is quite low, less than $0.1 \mathrm{~m}^{3} / \mathrm{h} / \mathrm{m}$, suggesting that only a few of the fractures in the shales are open and that these fractures occur within the uppermost $75 \mathrm{~m}$. Similar conditions are seen in many wells penetrating Danian limestone and Cretaceous chalk found near the surface, where fracture-based hydraulic conductivity is mainly found in the upper part, less than $70 \mathrm{~m}$ below the pre-
Quaternary surface. This is probably because the fractures were formed due to pressure release in connection with the last deglaciation. In contrast, the deep, water-bearing open fractures on Bornholm, as for instance observed in the Nexø Formation in the Borggård-1 well at a depth of $c .300 \mathrm{~m}$, were probably formed due to tectonic uplift.

\section{Conclusions}

New knowledge on the Palaeozoic geology of Bornholm has been gained since 2005 from five fully cored and geophysically logged scientific wells, re-logging of some water wells and acquisition of seismic data. A complete section of the Lower Palaeozoic has been pieced together by correlation of overlapping scientific well sections.

The research on Bornholm has provided detailed insight into the Palaeozoic stratigraphy and established a litho- and log-stratigraphical frame that is applicable in a regional context. Combined with ongoing drilling activities in northern Jylland this will provide a much better understanding of the evolution of the Palaeozoic in Denmark.

\section{Acknowledgements}

We are thankful to landowner Jette Staberg, Peter Turner of Faxe Kalk A/S, Kurt Nielsen of Rambøll and Klaus Bauer of GFZ. The greater part of the funding was received from Geocenter Denmark and Total E\&P Denmark B.V.

\section{References}

Bjerreskov, M. \& Jørgensen, K.Å. 1983: Late Wenlock graptolite-bearing tuffaceous sandstone from Bornholm, Denmark. Bulletin of the Geological Society of Denmark 31, 129-149.

Graversen, O. 2009: Structural analysis of superposed fault systems of the Bornholm horst block, Tornquist Zone, Denmark. Bulletin of the Geological Society of Denmark 57, 25-49.

Lassen, A. \& Thybo, H. 2012: Neoproterozoic and Palaeozoic evolution of SW Scandinavia based on integrated seismic interpretation. Precambrian Research 204-205, 75-104.

Nielsen, A.T., Klitten, K. \& Hansen, H.P.B. 2006: Borggård-1: en ny stratigrafisk kerneboring på Bornholm. Geologisk Nyt 6, 4-10.

Pedersen, G.K. \& Klitten, K. 1990: Anvendelse af gamma-logs ved korrelation af marine skifre i vandforsyningsboringer på Bornholm. Dansk Geologisk Forening Årsskrift 1987-89, 21-35.

Schovsbo, N.H., Nielsen, A.T., Klitten, K., Mathiesen, A. \& Rasmussen, P. 2011: Shale gas investigations in Denmark: Lower Palaeozoic shales on Bornholm. Geological Survey of Denmark and Greenland Bulletin 23, 9-13.

Authors' addresses

N.H.S. \& K.K., Geological Survey of Denmark and Greenland, Øster Voldgade 10, DK-1350 Copenhagen K, Denmark. E-mail:nsc@geus.dk

A.T.N., Natural History Museum of Denmark. Øster Voldgade 5-7, DK-1350 Copenhagen K, Denmark. 